\title{
Effect of nebulised L- and D-arginine on exhaled nitric oxide in steroid naive asthma
}

\author{
D C Chambers, J G Ayres
}

\begin{abstract}
Background-Nitric oxide (NO) is a product of the enzyme nitric oxide synthase (NOS) and is found in normal and asthmatic human airways. The administration of $L$-arginine results in an increase in airway NO production in asthmatic subjects. This is thought to occur because L-arginine is the substrate for NOS. However, studies in the systemic vasculature suggest that other mechanisms may be responsible.
\end{abstract}

Methods-Eight patients with steroid naive asthma each received $2.5 \mathrm{~g}$ L-arginine, $2.5 \mathrm{~g}$ D-arginine, and $2.0 \%$ saline by ultrasonic nebuliser on separate days in a randomised, single blind manner. Exhaled NO was measured by chemiluminescence and spirometric tests were performed before and for 3 hours after each administration. The mean concentration of NO after exposure was calculated from the area under the curve.

Results-L-arginine, D-arginine, and $2.0 \%$ saline induced a mean $(95 \% \mathrm{CI})$ maximal bronchoconstriction of $11.9 \%(-1.7$ to $25.4), 10.0 \%$ (2.8 to 17.2$)$, and $8.5 \%$ ( -2.5 to $19.5)$ of the starting forced expiratory volume in one second $\left(\mathrm{FEV}_{1}\right)$, respectively. Exhaled NO declined in proportion to the degree of bronchoconstriction $(r=0.60$, $\mathbf{p}<0.01)$. Bronchoconstriction and the acute reduction in exhaled NO resolved within 15 minutes. The mean postexposure concentration of NO was 15.75 parts per billion (ppb) after L-arginine, $15.16 \mathrm{ppb}$ after D-arginine, and $12.74 \mathrm{ppb}$ after $2.0 \%$ saline. The mean $(95 \% \mathrm{CI})$ difference between L-arginine and placebo was $3.01(0.32$ to 5.7$) \mathrm{ppb}$, between D-arginine and placebo $2.42 \quad(0.10$ to 4.74) ppb, and between $L-$ and D-arginine $0.59(-1.56$ to 2.74$) \mathrm{ppb}$.

Heartlands Research Institute, Birmingham Heartlands NHS Trust, Birmingham B9 5SS, UK

D C Chambers

J G Ayres

Correspondence to: Professor J G Ayres ayresj@heartsol.wmids.nhs.uk

Received 2 May 2000 Returned to authors 29 June 2000

Revised version received

6 November 2000

Accepted for publication

25 April 2001
Conclusions-Exhaled NO decreased with acute bronchoconstriction and returned to baseline with the resolution of bronchoconstriction. Exhaled NO increased following the administration of both L-arginine and D-arginine. Since NOS is stereospecific, this finding suggests that the increase in exhaled NO is not entirely mediated through an increase in NOS enzyme activity. We suggest that arginine may react in a non-stereospecific fashion with reactive oxygen species present in asthmatic airways.

(Thorax 2001;56:602-606)

Keywords: nitric oxide; arginine; asthma
Nitric oxide (NO) is found in increased amounts in the exhaled breath of patients with asthma and has been implicated in the pathophysiology of the disease. ${ }^{12} \mathrm{NO}$ is a gaseous product of the enzyme nitric oxide synthase (NOS), of which there are both constitutive (nNOS and eNOS) and inducible (iNOS) isoforms. The substrate for NOS is the amino acid L-arginine, and the enzyme is stereoisomer specific, suggesting that D-arginine will not act as a substrate for NOS.

The administration, either by nebulisation or orally, of L-arginine induces an increase in NO production in the respiratory tracts of normal and asthmatic subjects. ${ }^{3}$ L-arginine also prevents methacholine induced bronchoconstriction in isolated guinea pig tracheal segments through an NO dependent mechanism. ${ }^{5}$ These findings suggest that, in both normal and asthmatic airways, there is substrate limitation for NOS.

Nitric oxide has been much better studied in vascular tissue where it was originally described as endothelium derived relaxing factor (EDRF) whose main function is to dilate arteriolar smooth muscle. In the systemic vasculature L-arginine increased NO production by endothelial cells, ${ }^{6}$ an unexpected finding since the normal intracellular concentration of L-arginine in endothelial cells is well above the $\mathrm{Km}$ for NOS. ${ }^{78}$ One possible explanation is that NO may be formed from L-arginine non-enzymatically through reaction with reactive oxygen species such as hydrogen peroxide. ${ }^{9}$ Since asthma is associated with oxidative stress and the formation of reactive oxygen species, ${ }^{10}{ }^{11}$ it is possible that the increase in respiratory tract $\mathrm{NO}$ production after inhalation of L-arginine in asthmatic subjects may be at least partially mediated through a non-enzymatic route. If this is the case, then inhalation of D-arginine should lead to an increase in respiratory tract NO production similar to that observed after the inhalation of L-arginine. The aim of this study was to assess whether arginine induced increases in pulmonary NO production are stereospecific.

\section{Methods}

SUBJECTS

Eight non-smoking subjects with steroid naive asthma were studied. The diagnosis of asthma was based on the presence of circadian peak flow variability of more than $20 \%$ and/or evidence of spirometric reversibility (postbronchodilator forced expiratory volume in one second $\left(\mathrm{FEV}_{1}\right)$ more than $15 \%$ greater than pre-bronchodilator $\mathrm{FEV}_{1}$ ) in conjunction with appropriate symptoms (breathlessness, 
wheezing and cough). No subject had had an upper respiratory tract infection in the 4 weeks prior to the study. $\beta$ agonist medications were withheld on the morning of each visit. Subjects had not been exposed to inhaled steroid medication or to other glucocorticoids for at least 2 months before enrolment.

\section{STUDY DESIGN}

The study was of a randomised, single blind, crossover design and was approved by the East Birmingham local research and ethics committee. Each subject attended on three separate days, each at least 3 days apart. The concentration of exhaled NO was measured (mean of five measurements within 10\%) and spirometric tests were performed (best of three forced exhalations within 5\%) (VitalographCompact, Vitalograph Ltd, Buckingham, UK) at baseline. The spirometric tests were always performed after measurement of exhaled NO. The subjects then received either L-arginine (2.5 $\mathrm{g}$ in $20 \mathrm{ml} \mathrm{H} \mathrm{H}_{2}, 700 \mathrm{mOsm}, \mathrm{pH} \mathrm{6.1)}$, D-arginine $\left(2.5 \mathrm{~g}\right.$ in $20 \mathrm{ml} \mathrm{H} \mathrm{H}_{2} \mathrm{O}, 700 \mathrm{mOsm}$, $\mathrm{pH} 6.1$ ), or $2.0 \%$ saline control $(25 \mathrm{ml}$, 684 mOsm, pH 6.5 ) nebulised ultrasonically (Intersurgical, Wokingham, UK, output approximately $4 \mathrm{ml} / \mathrm{min}$ ). L- and $\mathrm{D}$-arginine were supplied by Clinalfa AG, Switzerland and $2.0 \%$ saline by Martindale Pharmaceuticals, Essex, UK. The concentration of exhaled NO was measured (mean of three measurements within $10 \%$ ) and spirometric tests were performed immediately after nebulisation and then again at $5,10,15,30,45,60,90,120,150$ and 180 minutes after nebulisation. A single administration of $100 \mu \mathrm{g}$ salbutamol by inhalation was allowed if the initial post-nebuliser

Table 1 Demographic details for eight subjects with steroid naive asthma

\begin{tabular}{lllllllll}
\hline Subject & Age & Sex & $F E V_{1}$ (l) & $\begin{array}{l}F E V_{1} \\
(\%)\end{array}$ & FVC (l) & $\begin{array}{l}F V C \\
(\%)\end{array}$ & $\begin{array}{l}\text { NO } \\
(p p b)\end{array}$ & $\begin{array}{l}\text { Salbutamol } \\
\text { required }\end{array}$ \\
\hline 1 & 46 & $\mathrm{~F}$ & 1.84 & 65 & 3.11 & 94.3 & 23.9 & $\mathrm{Y}$ \\
2 & 28 & $\mathrm{~F}$ & 2.81 & 79.3 & 4.01 & 99 & 8.5 & $\mathrm{Y}$ \\
3 & 25 & $\mathrm{~F}$ & 3.34 & 95.7 & 3.77 & 94.3 & 8.4 & $\mathrm{~N}$ \\
4 & 54 & $\mathrm{~F}$ & 1.92 & 72.3 & 3.07 & 98.5 & 5.6 & $\mathrm{~N}$ \\
5 & 26 & $\mathrm{~F}$ & 2.84 & 95 & 3.51 & 102.3 & 20.4 & $\mathrm{~N}$ \\
6 & 28 & $\mathrm{M}$ & 3.69 & 84.7 & 5.01 & 97.3 & 29.7 & $\mathrm{Y}$ \\
7 & 25 & $\mathrm{~F}$ & 2.85 & 79.7 & 4.21 & 103 & 3.8 & $\mathrm{Y}$ \\
8 & 24 & $\mathrm{~F}$ & 3.00 & 88 & 3.58 & 92 & 6.6 & $\mathrm{~N}$
\end{tabular}

$\mathrm{FEV}_{1}=$ forced expiratory volume in one second; $\mathrm{FVC}=$ forced vital capacity NO = nitric oxide

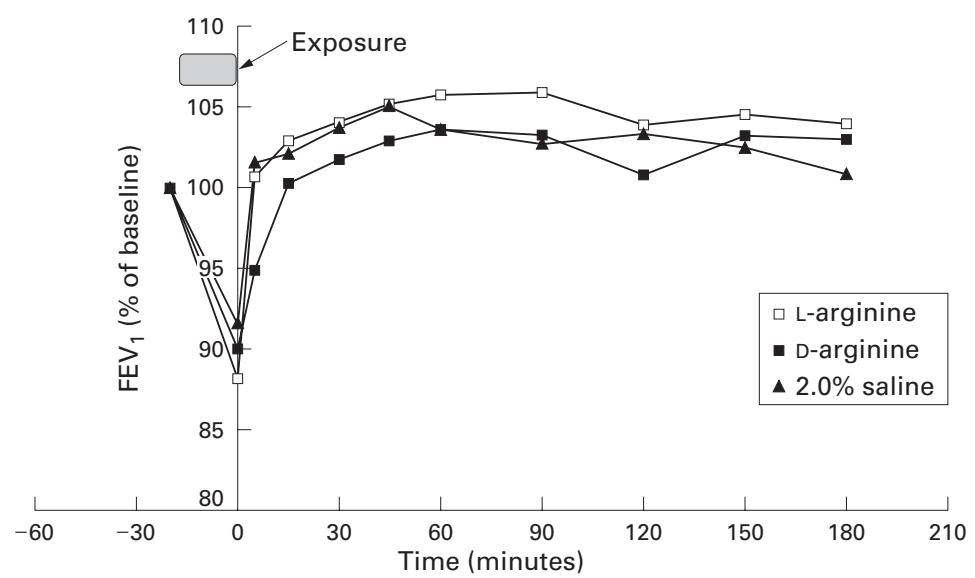

Figure 1 Effect of $L^{-}$-and D-arginine $(2.5 \mathrm{~g})$ and $2.0 \%$ saline inhalation on $F E V_{1}$ in patients with steroid naive asthma $(n=8)$.
$\mathrm{FEV}_{1}$ revealed a significant $(>10 \%)$ bronchoconstriction.

ASSESSMENT OF EXHALED NO

Exhaled NO was measured by chemiluminescence (LR2000, Logan Research, Kent, UK) in accordance with European Respiratory Society guidelines ${ }^{12}$ as previously described. ${ }^{13}$ Briefly, subjects inhaled to total lung capacity and then completed a slow vital capacity exhalation through a resistance with a flow meter in series. A visual feedback display allowed the subject to maintain a flow rate of approximately $200 \mathrm{ml} / \mathrm{s}$ during the exhalation, while the resistance maintained closure of the soft palate. Nose clips were not used. The chemiluminescence analyser sampled the exhalate in real time at $250 \mathrm{ml} / \mathrm{min}(4.2 \mathrm{ml} / \mathrm{s})$ with a sensitivity of 0.3 parts per billion (ppb) and a sampling rate of $15 \mathrm{~Hz}$. Calibration was performed daily. The exhaled NO measurement was obtained from the plateau phase at $75 \%$ of exhaled volume. ${ }^{13}$

\section{STATISTICAL ANALYSIS}

Exhaled NO and $\mathrm{FEV}_{1}$ (as \% of baseline) are presented graphically as the mean at each time point for each visit. The change in $\mathrm{FEV}_{1}$ immediately following exposure was tested for statistical significance using a paired $t$ test. In order for comparisons to be made between exposure groups, the serial measures were summarised for each individual for each exposure from baseline to 180 minutes after exposure using the area under the curve method ${ }^{14}$ and expressed as an absolute amount by dividing by total time. Statistical significance was tested using paired $t$ tests. A potential correlation between change in exhaled NO concentration and change in $\mathrm{FEV}_{1}$ within each subject was sought using multiple linear regression and dummy variables according to the method described by Bland and Altman. ${ }^{15}$

\section{Results}

Demographic and lung function data for the eight subjects are shown in table 1 . Subjects who required salbutamol to relieve acute bronchoconstriction required it for all three visits. Immediately after exposure, L-arginine, $\mathrm{D}$-arginine, and $2.0 \%$ saline induced a mean (95\% CI) bronchoconstriction of $11.9 \%(-1.7$ to $25.4, \mathrm{p}=0.08), 10.0 \%$ (2.8 to $17.2, \mathrm{p}<0.01)$, and $8.5 \%(-2.5$ to $19.5, \mathrm{p}=0.17)$ of the starting $\mathrm{FEV}_{1}$, respectively, although the degree of induced bronchoconstriction varied widely (from a $2 \%$ increase in $\mathrm{FEV}_{1}$ to a $38 \%$ decrease). These decrements in $\mathrm{FEV}_{1}$ were associated with a reduction in exhaled NO (figs 1 and 2) which correlated well with the reduction in $\mathrm{FEV}_{1}$ (fig 3, $r=0.60, \mathrm{p}<0.01$ ). In all groups bronchoconstriction resolved within 15 minutes (fig 1) and exhaled NO returned to pre-exposure levels with the resolution of bronchoconstriction (fig 2). There were no differences in mean post-exposure $\mathrm{FEV}_{1}$ between the L-arginine, D-arginine, and $2.0 \%$ saline groups.

The mean post-exposure concentrations of NO were $15.75 \mathrm{ppb}, 16.16 \mathrm{ppb}$, and $12.74 \mathrm{ppb}$ in the L-arginine, D-arginine, and 


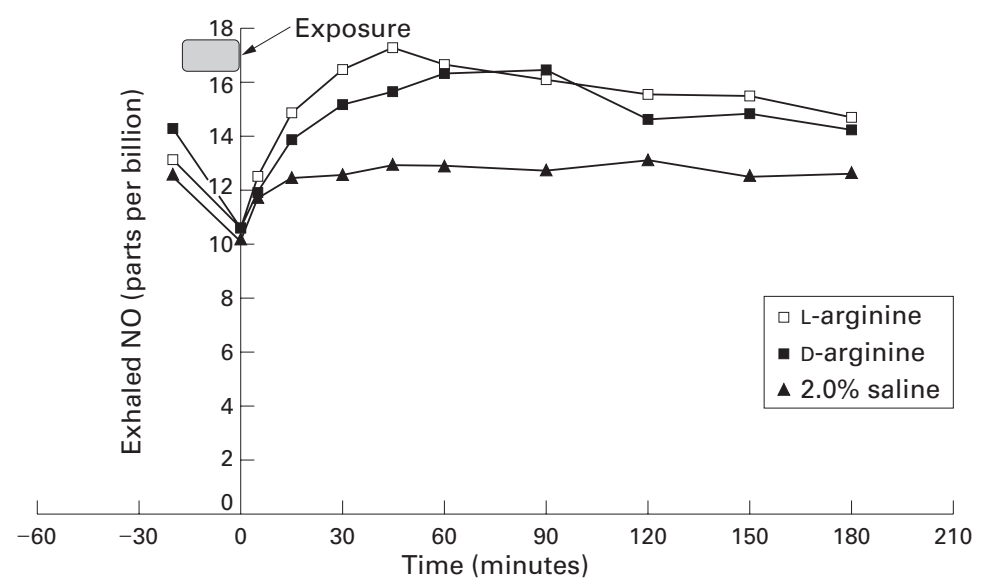

Figure 2 Effect of $L$-and D-arginine $(2.5 \mathrm{~g})$ and $2.0 \%$ saline inhalation on exhaled $N O$ in patients with steroid naive asthma $(n=8)$.

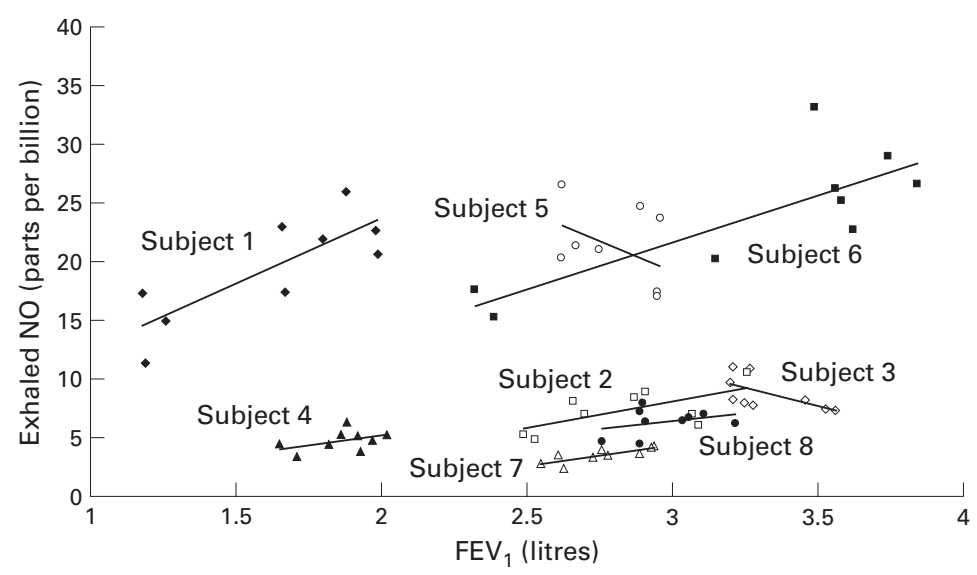

Figure 3 Within subject relationship between FEV and exhaled NO during acute bronchoconstriction $(n=8, r=0.60, p<0.01)$.

$2.0 \%$ saline groups, respectively. For both L-arginine and D-arginine the mean postexposure concentration of NO was significantly different from placebo $(\mathrm{p}<0.05$ in each case). There was no difference in post-exposure NO concentration between L- and D-arginine $(p=0.54)$. The mean (95\% CI) difference between L-arginine and placebo was $3.01(0.32$ to 5.70$) \mathrm{ppb}$, between $\mathrm{D}$-arginine and placebo $2.42(0.10$ to 4.74$) \mathrm{ppb}$, and between $\mathrm{L}-$ and D-arginine 0.59 (-1.56 to 2.74$) \mathrm{ppb}$.

\section{Discussion}

Several lines of evidence support the idea that $\mathrm{NO}$ is important in the pathophysiology of asthma. Firstly, it has been well shown that NO concentrations are increased in the exhaled breath of patients with asthma. ${ }^{2}$ Secondly, in patients with asthma, exhaled NO concentrations correlate with markers of airway hyperresponsiveness. ${ }^{16-19}$ Thirdly, inhibition of NO production has increased airway hyperresponsiveness in guinea pig $^{20-22}$ and human airways. ${ }^{23}$ Factors which alter NO metabolism in the airways are therefore of potential significance in asthma. Most work has centred around factors which alter NOS activity or induction as these are thought to be most important in controlling NO metabolism. In this study we have studied effects on NO metabolism independent of enzyme activity or induction.

We have shown that exhaled NO increases after the administration by nebulisation of both L- and D-arginine relative to $2.0 \%$ saline control in subjects with steroid naive asthma. Additionally, acute bronchoconstriction is associated with a reduction in exhaled NO which closely parallels the reduction in $\mathrm{FEV}_{1}$. Exhaled NO concentrations return to baseline with the resolution of bronchoconstriction.

The time course and magnitude of the change in respiratory tract NO production after the administration of $2.5 \mathrm{~g} \mathrm{~L}$-arginine is in good agreement with that reported by Sapienza et al after the administration of $3 \mathrm{~g}$ L-arginine, also by ultrasonic nebulisation. ${ }^{4}$ L-arginine may increase NO production through increased provision of substrate to NOS, as suggested by Sapienza et al. ${ }^{4}$ However, studies in the systemic vasculature, where NO was originally described as endothelium derived relaxing factor, cast doubt on this theory. Although the administration of $\mathrm{L}$-arginine is able to increase NO production in the systemic vasculature in an analogous fashion to that reported by Sapienza et $a l^{4}$ and to our findings in the lung, the intracellular concentration of L-arginine in endothelial cells is several orders of magnitude higher than the $\mathrm{Km}$ for $\mathrm{NOS},{ }^{24}$ so it makes sense on theoretical grounds that increased substrate provision should not influence enzyme activity. Although intracellular concentrations of L-arginine have, to our knowledge, not been measured in asthmatic airways, Sapienza et al speculate that increased NOS activity in these inflamed airways leads to a relative deficiency of $\mathrm{L}$-arginine so that concentrations are low enough to be able to demonstrate substrate dependence of enzyme activity. ${ }^{4}$ However, they also found an increase in NO production after the administration of L-arginine in subjects with normal airways. ${ }^{4}$

There are a number of possible alternative explanations for these findings. Increased production of NO in the respiratory tract may be a protective response to the acute bronchoconstriction induced immediately after exposure, since NO may play a role as a bronchodilator. ${ }^{17}$ Against this theory, however, is the absence of an increase in NO production after the bronchoconstriction induced by exposure to $2.0 \%$ saline. Alternatively, L- and D-arginine may act as non-specific irritants which induce an inflammatory response in the airways, including upregulation or induction of NOS. However, NOS induction occurs over a period of hours after exposure to the irritant ${ }^{25}$ and a similar response may be expected after the administration of $2.0 \%$ saline.

Nagase and coworkers have recently described a novel non-enzymatic pathway for the generation of NO through the reaction of hydrogen peroxide with arginine. ${ }^{9}$ This reaction is not stereospecific and has been proposed as a possible explanation for the substrate dependence of NOS activity in the systemic vasculature. The concentrations of arginine and hydrogen peroxide required for the spontaneous formation of $\mathrm{NO}$ are in the 
millimolar range. Currently, the only estimates of the concentration of hydrogen peroxide in asthmatic airways come from work with breath condensates. Jobsis et $a l^{26}$ found a median concentration of hydrogen peroxide of $0.6 \mu \mathrm{mol}$ in the breath condensate of patients with stable asthma. Although this is lower than that required for the spontaneous formation of $\mathrm{NO}$, it may be that higher concentrations of hydrogen peroxide are reached locally in inflamed asthmatic airways. The large doses of arginine administered in this study and the study of Sapienza $e t a l^{4}$ may lead to sufficiently high local airway concentrations of arginine for this reaction to become a significant source of NO.

Hunt et $a l^{7}$ have recently shown that asthmatic airways are acidic during acute asthma and that this acidity resolves with treatment. They speculate that local airway chemistry may play a much more important role in the pathogenesis of asthma than previously thought. They also suggest that changes in airway chemistry are responsible for the increased pulmonary production of $\mathrm{NO}$ in asthma. ${ }^{27}{ }^{28}$ Given that the $\mathrm{pH}$ of the saline control in this study was 6.5 while that of Land $\mathrm{D}$-arginine was 6.1 , it is possible that airway acidification may have contributed to the increase in exhaled $\mathrm{NO}$ in the arginine groups. Against this suggestion is the finding that the administration of L-arginine orally in a dose of 0.1 and $0.2 \mathrm{mg} / \mathrm{kg}$ also increases exhaled NO. ${ }^{3}$ It is difficult to imagine an oral dose significantly altering airway $\mathrm{pH}$. In addition, the $\mathrm{pH}$ found in exhaled breath condensate by Hunt and colleagues was very much lower and it is far from certain whether the change in $\mathrm{pH}$ found in acute asthma was the cause of, or associated with, an exacerbation of asthma. Regardless of the mechanism, in demonstrating that alterations in NOS activity and induction may not be entirely responsible for the alterations in NO production observed in asthma, our findings are complementary to those of Hunt et al..$^{27}$

We have shown that exhaled NO concentrations decrease in parallel with decrements in $\mathrm{FEV}_{1}$ during acute bronchoconstriction and return to baseline with the resolution of bronchoconstriction. In our study, bronchoconstriction was inadvertently induced by the administration by nebulisation of hypertonic solutions of L-arginine, D-arginine, and saline. A decrease in exhaled NO concurrent with acute bronchoconstriction and its resolution with bronchodilation has been well described previously ${ }^{29-31}$ but the mechanism remains unknown. In particular, it is not known whether the decrease in exhaled NO is causal or merely associated with bronchoconstriction. The simplest explanation would be that the bronchial epithelial surface area declines with bronchoconstriction, so reducing the available area from which NO may diffuse toward the lumen. However, James et al have shown that the bronchial mucosa concertinas with bronchoconstriction so that the epithelial surface area remains constant. ${ }^{32}$ Alternatively, the thickness of the epithelial lining fluid (ELF) may increase with bronchoconstriction as airway diameter decreases. Thickening and increased tenacity of the ELF is thought to be the mechanism for the reduction in exhaled $\mathrm{NO}$ in patients with cystic fibrosis. ${ }^{33}$ Another explanation which remains completely unexplored is that the decrease in exhaled NO is a primary event and gives rise to bronchoconstriction. Further work in this area will provide further insight into the pulmonary physiology of NO.

In summary, we describe an increase in the concentration of exhaled NO after the administration of both $\mathrm{L}$ - and $\mathrm{D}$-arginine relative to $2.0 \%$ saline control in subjects with steroid naive asthma, and acute decreases in exhaled NO concurrent with and in proportion to bronchoconstriction. The increase in exhaled $\mathrm{NO}$ after D-arginine suggests that this effect is not entirely mediated through NOS. We suggest that arginine may react directly with hydrogen peroxide present in asthmatic airways to form $\mathrm{NO}$ and that changes in airway chemistry (for instance redox state) may modulate NO release with potential pathophysiological consequences.

1 Alving K, Weitzberg E, Lundberg JM. Increased amount of nitric oxide in exhaled air of asthmatics. Eur Respir $\mathcal{F}$ 1993;6:1368-70.

2 Kharitonov SA, Chung KF, Evans D, et al. Increased exhaled nitric oxide in asthma is mainly derived from the ower respiratory tract. Am $f$ Respir Crit Care Med 1996;153:1773-80.

3 Kharitonov SA, Lubec G, Lubec B, et al. L-arginine increases exhaled nitric oxide in normal human subjects. Clin Sci (Colch) 1995;88:135-9.

4 Sapienza MA, Kharitonov SA, Horvath I, et al. Effect of Sapienza MA, Kharitonov SA, Horvath I, et al. Effect of
inhaled L-arginine on exhaled nitric oxide in normal and inhaled L-arginine on exhaled nitric oxide

5 Meurs H, de Boer J, Duyvendak M, et al. Role of L-arginine in the deficiency of nitric oxide and airway hyperreactivity after the allergen-induced early asthmatic reaction in guinea pigs. Am F Respir Crit Care Med 1999;159:A867.

6 Drexler H, Zeiher AM, Meinzer K, et al. Correction of endothelial dysfunction in the coronary microcirculation of hypercholesterolaemic patients by L-arginine. Lancet 1991; 338:1546-50

7 Ueda S, Petrie JR, Cleland SJ, et al. Insulin vasodilatation and the "arginine paradox". Lancet 1998;351:959-60.

8 Arnal JF, Flores P, Rami J, et al. Nasal nitric oxide concentration in paranasal sinus inflammatory diseases. Eur Respir f 1999;13:307-12.

9 Nagase S, Takemura K, Ueda A, et al. A novel nonenzymatic pathway for the generation of nitric oxide by the reaction of hydrogen peroxide and D- or L-arginine. Biochem Biophys Res Commun $1997 ; 233: 150-3$.

10 Vachier I, Chanez P, Le Doucen C, et al. Enhancement of reactive oxygen species formation in stable and unstable asthmatic patients. Eur Respir f 1994; 7:1585-92.

11 Rahman I, Morrison D, Donaldson K, et al. Systemic oxidative stress in asthma, COPD, and smokers. $\mathrm{Am} \mathcal{F}$ Respir Crit Care Med 1996;154:1055-60.

12 Kharitonov S, Alving K, Barnes PJ. Exhaled and nasal nitric oxide measurements: recommendations. The European Respiratory Society Task Force. Eur Respir f 1997;10: 1683-93.

13 Chambers DC, Tunnicliffe WS, Fletcher TJ, et al. Measurement of lower respiratory tract nitric oxide: validity of using
values at $75 \%$ of exhaled volume. Thorax 1996;51:A17.

14 Matthews JNS, Altman DG, Campbell MJ, et al. Analysis of Matthews JNS, Altman DG, Campbell MJ, et al. Analysis of
serial measurements in medical research. BMF 1990;300: serial m.

15 Bland JM, Altman DG. Calculating correlation coefficients with repeated observations: Part 1 . Correlation within subjects. BMF 1995;310:446

16 Dupont LJ, Rochette F, Demedts MG, et al. Exhaled nitric oxide correlates with airway hyperresponsiveness in steroid-naive patients with mild asthma. Am $\mathcal{F}$ Respir Crit Care Med 1998;157:894-8.

17 Inoue $\mathrm{H}$, Hara $\mathrm{N}$, Aizawa $\mathrm{H}$, et al. Inhibitory role of nitric oxide derived from i-NANC on airway hyperresponsiveness in asthmatics. Am $\mathcal{F}$ Respir Crit Care Med 1999;159: A409.

18 Jatakanon A, Lim S, Kharitonov SA, et al. Correlation between exhaled nitric oxide, sputum eosinophils, and methacholine responsiveness in patients with mild asthma. Thorax 1998;53:91-5.

19 Silkoff PE, McClean PA, Slutsky AS, et al. Exhaled nitric oxide and bronchial reactivity during and after inhaled beclomethasone in mild asthma. F Asthma 1998;35:473-9. 
20 Nijkamp FP, van der Linde HJ, Folkerts G. Nitric oxide synthesis inhibitors induce airway hyperresponsiveness in the guinea pig in vivo and in vitro. R

21 Ricciardolo FLM, Geppetti P, Nadel JA, et al. Nitric oxide synthase inhibitors worsen bronchoconstriction induced by neurokinin-A in guinea pigs in vivo. Eur Respir $\mathcal{F}$ 1998;12:116s.

22 Yoshihara S, Nadel JA, Figini M, et al. Endogenous nitric oxide inhibits bronchoconstriction induced by cold air inhalation in guinea pigs: role of kinins. Am $\mathcal{F}$ Respir Crit Care Med 1998;157:547-52.

23 Taylor DA, McGrath JL, Orr LM, et al. Effect of endogenous nitric oxide inhibition on airway responsiveness to histamine and adenosine-5'-monophosphate in asthma. Thorax 1998;53:483-9.

24 Hecker M, Sessa WC, Harris HJ, et al. The metabolism of L-arginine and its significance for the biosynthesis of endothelium-derived relaxing factor: cultured endothelial cells recycle L-citrulline to L-arginine. Proc Natl Acad Sci USA 1990;87:8612-6.

25 Pendino KJ, Laskin JD, Shuler RL, et al. Enhanced production of nitric oxide by rat alveolar macrophages after inhalation of a pulmonary irritant is associated with increased expression of nitric oxide synthase. F Immunol 1993;151 7196-205.
26 Jobsis Q, Raatgeep MC, Hermans PW, et al. Hydrogen peroxide in exhaled air is increased in stable asthmatic oxide in exhaled air is increased in
children. Eur Respir 7 1997;10:519-21.

27 Hunt JF, Fang K, Malik R, et al. Endogenous airway acidification. Implications for asthma pathophysiology. Am J Respir Crit Care Med 2000;161:694-9.

28 Marshall HE, Stamler JS. NO waiting to exhale in asthma. Am f Respir Crit Care Med 2000;161:685-7.

29 Ho CF, Wang CH, Liu CY, et al. The effect of bronchodilators on exhaled nitric oxide (NO) in patients with bronchial asthma. Eur Respir F 1997;10:102s.

30 de Gouw HWFM, Hendriks J, Twiss IM. Exhaled nitric oxide (NO) is reduced shortly after AMP- and histamineinduced bronchoconstriction in asthma. Eur Respir f 1997; 10:158s.

31 de Gouw HW, Hendriks J, Woltman AM, et al. Exhaled nitric oxide (NO) is reduced shortly after bronchoconstriction to direct and indirect stimuli in asthma. Am $\mathcal{F}$ Respir Crit Care Med 1998;158:315-9.

32 James AL, Hogg JC, Dunn LA, et al. The use of the internal perimeter to compare airway size and to calculate smooth perimeter to compare airway size and to calculate smo
muscle shortening. Am Rev Respir Dis 1988;138:136-9.

33 Linnane SJ, Keatings VM, Costello CM, et al. Total sputum nitrate plus nitrite is raised during acute pulmonary infection in cystic fibrosis. Am $\mathcal{F}$ Respir Crit Care Med 1998;158: 207-12.

\title{
Narrative Based Medicine, An Interdisciplinary Conference
}

\author{
Research, Narrative, and Practice
}

A two day conference-Monday 3rd and Tuesday 4th September 2001

\section{Homerton College, Cambridge, UK}

\section{BMF Publishing Group}

For full details contact: BMA/BMJ Conference Unit, Tavistock Square, London, WC1H 9JP Tel: +44 (0)20 7383 6819; fax: +44 (0)20 7383 6663; email: clyders@bma.org.uk.

www.quality.bmjpg.com 